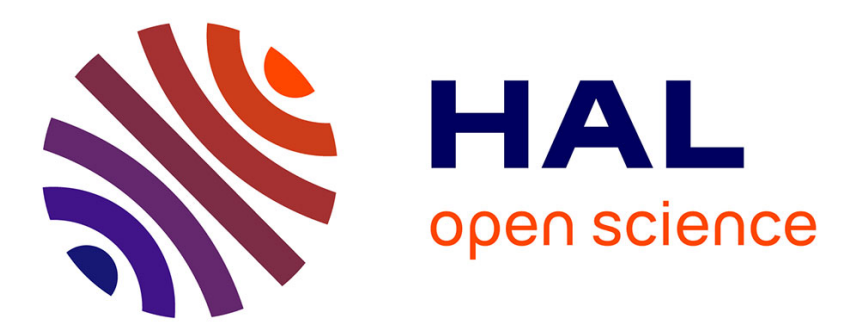

\title{
Revision of freshwater shrimps belonging to Caridina weberi complex (Crustacea: Decapoda: Atyidae) from Polynesia with discussion on their biogeography
}

Valentin de Mazancourt, Gérard Marquet, Philippe Keith

\section{To cite this version:}

Valentin de Mazancourt, Gérard Marquet, Philippe Keith. Revision of freshwater shrimps belonging to Caridina weberi complex (Crustacea: Decapoda: Atyidae) from Polynesia with discussion on their biogeography. Journal of Natural History, 2019, 53 (13-14), pp.815-847. 10.1080/00222933.2019.1612959 . hal-02171198

\section{HAL Id: hal-02171198 \\ https://hal.science/hal-02171198}

Submitted on 2 Jul 2019

HAL is a multi-disciplinary open access archive for the deposit and dissemination of scientific research documents, whether they are published or not. The documents may come from teaching and research institutions in France or abroad, or from public or private research centers.
L'archive ouverte pluridisciplinaire HAL, est destinée au dépôt et à la diffusion de documents scientifiques de niveau recherche, publiés ou non, émanant des établissements d'enseignement et de recherche français ou étrangers, des laboratoires publics ou privés. 
1 Revision of freshwater shrimps belonging to Caridina weberi complex

2 (Crustacea: Decapoda: Atyidae) from Polynesia with discussion on their

3 biogeography.

4 Valentin de Mazancourt ${ }^{1 *}$, Gérard Marquet ${ }^{1}$ and Philippe Keith ${ }^{1}$

$5 \quad$ I Muséum national d'Histoire naturelle, Département Adaptations du Vivant, UMR 7208

6 BOREA, CP026, 57, rue Cuvier, F-75231 Paris, Cedex 05

$7 \quad{ }^{*}$ Corresponding author. E-mail: valentin.demazancourt@laposte.net

8 


\section{Revision of freshwater shrimps belonging to Caridina weberi complex}

10 (Crustacea: Decapoda: Atyidae) from Polynesia with discussion on their

11 biogeography.

Caridina weberi, an emblematic species of the ' $C$. weberi complex', was described by De Man in 1892 from different localities in Indonesia. Until now, this species was thought to have a wide distribution in Polynesia. Numerous specimens identified as $C$. weberi were collected recently from various Polynesian islands. In the context of an integrative taxonomy, they were morphologically and genetically studied. Three new species allied to $C$. weberi are here described: C. marquesensis n. sp., C. futunensis n. sp. and $C$. tupaia n. sp.. The occurence of $C$. rapaensis, another species part of the ' $C$. weberi' complex is confirmed. Descriptions or redescription of these species are given as well as their geographical and ecological distributions. The position of these species in the complex is clarified. A key is provided to facilitate identification.

Keywords: 16S, genetic, morphology, integrative taxonomy, freshwater shrimp.

\section{Introduction}

The freshwater shrimp genus Caridina, comprising 298 species (WoRMS database, as of May 2018) and mostly present in the Indo-Pacific region, is the most diversified genus of the Atyidae (De Grave et al. 2015) and an important ecological component in the tropical streams (Covich et al. 1999; Pringle et al. 1993). Its high diversity combined with the lack of informative morphological characters has led to a confused taxonomy (Richard and Clark 2009). Indeed, until recently, the taxonomy of the genus was mainly based on morphological characters. Some have been proven highly variable within a species (e.g. rostrum shape and indentation or coloration) and so taxonomically non-informative, making it difficult to 
establish boundaries between them (Rintelen and Cai 2009; Mazancourt et al. 2017). Thus, there is a need for an integrative and standardized approach to improve the group's systematics, focusing on informative morphological features and using molecular characters (Page et al. 2005; Page and Hughes 2011).

To illustrate this problem, we focus here on species of the troublesome ' $C$. weberi complex'. The taxonomic complexity within the genus Caridina has led previous authors to create groups of species based on morphological characters they share. For example, Bouvier (1925) defined 5 species group: C. nilotica group, C. laevis group, C. africana group, $C$. brevirostris group and C. typus group. Some of these groups have been split to create new ones as new species were described, such as C. serrata (Cai and Ng 1999; Karge and Klotz 2007), C. gracilirostris (Cai and Ng 2007) and C. weberi (Cai and Anker 2004; Cai et al. 2009) while others still exist to this day, like $C$. nilotica and C. typus groups (Karge and Klotz 2007).

Polynesia forms a triangle between Hawaii, New Zealand and Easter Island (Figure 1). We can distinguish Northern Polynesia (Hawaii), Western Polynesia (Tuvalu, Tokelau, Wallis and Futuna, Tonga, Niu, Samoa islands, Cook Islands) and Eastern Polynesia (French Polynesia, Pitcairn Island and Eastern Island). The occurrence of $C$. weberi in Polynesia has been reported by Edmondson (1935), Adamson (1935, 1939), Marquet (1988, 1991), Fossati and Marquet (1998), Keith and Vigneux (2002), Keith et al. (2002), Keith and Marquet (2011), and Keith et al. (2013).

Streams of Austral, Society and Marquesas Islands (French Polynesia) were prospected by the Muséum national d'Histoire naturelle (MNHN, Paris) from 1983 to 2001 and recently in September and October 2017, rivers of Futuna (Territory of Wallis and Futuna islands) in October 2004, rivers of Rarotonga (Cook islands) in July 2010, rivers of Upolu (Samoa) in July 2008 and August 2014. One of the aims of the MNHN is to carry out 
faunistic inventories of rivers in tropical islands in order to establish a better protection of these fragile ecosystems and, in this context, to clarify the taxonomy of poorly known organisms. As we collected more and more specimens from different islands from Polynesia, we started to raise doubts regarding the validity of $C$. weberi in this area. Thereby, in combining morphological data with a $16 \mathrm{~S}$ mtDNA analysis, we identified three new species and confirmed the presence of $C$. rapaensis. The aim of this study is to describe or re-describe them and to compare them to type specimens of species belonging to the $C$. weberi complex.

\section{Material and methods}

\section{Collection of specimens}

Specimens from Polynesia were collected by electrofishing (portable Dekka 3,000 electric device, Germany or SAMUS 1,000, Poland: http://www.electro-fisher.net/). All material preserved in 75\%-95\% alcohol has been deposited in the collections of the Muséum national d'Histoire naturelle in Paris (MNHN). A total of 42 recent specimens (33 identified as $C$. weberi from various Polynesian islands and 9 identified as $C$. rapaensis from Rapa and Rurutu islands) were morphologically studied. As comparative material, syntypes of $C$. weberi (MNHN-IU-2015-1755) and C. parvirostris (MNHN-IU-2015-1748 and MNHN-IU2015-1754) preserved in the MNHN collections and type specimens of C. rapaensis (Holotype BPBM 53933 and paratype BPBM 53694) preserved in the Bernice Pauahi Bishop Museum collections (BPBM, Hawaii, USA) were examined.

\section{DNA extraction, amplification and sequencing}

DNA was extracted from abdominal tissues from 29 specimens using the semiautomatic Eppendorf ep-Motion 5075 robot with the Nucleospin ${ }^{\circledR}$ Tissue kit (MachereyNagel, Düren, Germany), following the manufacturer's instructions. Extracted DNA was 
stored at $-20^{\circ} \mathrm{C}$. Fragments of the mitochondrial $16 \mathrm{~S}$ rRNA $(\sim 520 \mathrm{bp})$ were amplified using primers, adapted from Palumbi (1996) to our taxa: 16Sar-Lmod (5'-

TACTTCTGCCTGTTTATCAAAAA-3') and 16Sbmod (5'-

GGTCTGAACTCAAATCATGTAAA-3'). DNA amplification was performed in $20 \mu 1$ PCR reactions, containing approximately $3 \mathrm{ng}$ of template DNA, $2.5 \mathrm{mM} \mathrm{MgCl}_{2}, 0.26 \mathrm{mM}$ of each nucleotide, $0.3 \mu \mathrm{M}$ of each primer, $5 \%$ DMSO, 1ng of BSA and 1.5 units of QBIOTAQ polymerase (MPBiomedicals). Amplification products were generated by an initial denaturation step of $4 \mathrm{~min}$ at $94^{\circ} \mathrm{C}$ followed by 35 cycles of denaturation at $94^{\circ} \mathrm{C}$ for $30 \mathrm{~s}$, annealing at $52^{\circ} \mathrm{C}$ for $40 \mathrm{~s}$, extension at $72^{\circ} \mathrm{C}$ for $60 \mathrm{~s}$ and a final extension step at $72^{\circ} \mathrm{C}$ for 7 min. PCR products were sequenced using the same primers and in both directions to ensure the accuracy of base calls. Chromatograms were edited using Geneious v.8 software (http://www.geneious.com/ Kearse et al. 2012). All sequences were deposited in GenBank (Accession numbers XXXXXXXXXX to XXXXXXXXXX, Table 1).

\section{Phylogenetic analyses}

DNA sequences were aligned using MEGA7 software (Kumar et al. 2016) with Muscle algorithm (Edgar 2004). Best-fit molecular evolution model was selected using Bayesian information criterion in jModelTest (Darriba et al. 2012; Guindon and Gascuel 2003). Molecular p-distances among aligned sequences were calculated with MEGA7. Bestscoring ML trees were estimated using RAxML HPC2 v.8.2.10 (Stamatakis 2014) and bestscoring Bayesian Inference trees were estimated using MrBayes v.3.2.6 (Ronquist and Huelsenbeck 2003), both methods implemented in the Cyber Infrastructure for Phylogenetic Research (CIPRES) portal v.3.1. (Miller et al. 2010, https://www.phylo.org/) with the previously determined model, running two separate analyses for 5,000,000 generations, a sampling frequency of 1,000 and a burn in of $25 \%$. Convergence was assessed by comparing 
108 the two runs in Tracer v.1.6 (http://tree.bio.ed.ac.uk/software/tracer/). Support for nodes was

109 determined using posterior probabilities (PP) calculated by MrBayes implemented CIPRES.

110 For ML trees, one hundred independent searches, each starting from distinct random trees,

111 were conducted to assess robustness of the nodes using non-parametric bootstrapping

112 (Felsenstein 1985) with 1,000 bootstrap replicates (B). A total of 30 specimens were included

113 in the analysis, 27 initially identified as $C$. weberi collected in various Polynesian islands and

1143 identified as C. rapaensis from Rapa (Table 1), plus a sequence from Macrobrachium

115 australe published by Page et al. (2007a) to root the tree (Accession number: DQ681290).

117 (Table 1 near here)

Automatic species delimitation methods

Three different methods were used. First, ABGD (Puillandre et al. 2012) implemented

121 on the web server http://wwwabi.snv.jussieu.fr/public/abgd/abgdweb.html, for which a

122 pairwise distances matrix was built from the sequences alignment using JC69 Jukes-Cantor

123 model. We used Pmin $=0.001$ and $P \max =0.4$ with 20 steps and $X=1.5$. A graphical

124 representation of the distribution of the distances showed a barcoding gap between 0.03 and

1250.1 divergence. Second, we ran a bPTP analysis (Zhang et al. 2013) from the web server

126 http://species.h-its.org/ptp/ using the ML tree as input specifying M. australe as outgroup.

127 Other parameters were left as default. Finally, we used the GMYC method (Pons et al. 2006)

128 implemented in the web server https://species.h-its.org/gmyc/ using only the single threshold

129 method (phylogeny composed of several species with one coalescent time value) as species

130 studied are phylogenetically close to each other. To run this analysis, an ultrametric tree is

131 required, which was constructed using BEAST v. 1.8.3 (Drummond and Rambaut 2007). We

132 used a relaxed lognormal clock with a coalescent tree prior as these have been identified as 
133 best prior parameters for GMYC analyses (Esselstyn et al. 2012; Monaghan et al. 2009).

134 Monte Carlo Markov chains (MCMC) ran for 35,000,000 generations, sampling every 1000

135 generations. Chains convergence was assessed using Tracer v.1.6 (Rambaut et al. 2014). The

136 consensus tree (maximum clade credibility tree; $10 \%$ burn in; tree not presented) was

137 constructed with TreeAnnotator v.1.8.3 (Rambaut and Drummond 2016).

Abbreviations for morphological analyses

The following abbreviations are used in the present text: cl, carapace length (mm):

141 measured from the post-orbital margin to the posterior margin of the carapace. P1: first

142 pereopod. P2: second pereopod. P3: third pereopod. P5: fifth pereopod. P11: first pleopod.

143 P12: second pleopod.

\section{Morphological comparison}

The rostrum, the general cephalon, the pereopods 1, 2, 3 and 5 and the abdomen were observed using a stereoscopic microscope. The proportions of the various joints of the appendages were measured using microphotographs and AnalySIS Works software

149 (Olympus). Drawings were made using the 'Digital Inking' method (Coleman 2003, 2006) by tracing vectorial paths on stacks of high-resolution photographs using Adobe Illustrator (CS3) and a WACOM PTZ-1230 graphic tablet.

\section{Results}

\section{Phylogenetic analyses}

Following the analysis by jModelTest, we retained the GTR $+\mathrm{G}$ model as the best to

156 fit our data. As the trees obtained from the two methods were congruent for the main clusters,

157 we present here the one obtained from the Bayesian Inference analysis with the posterior 
158 probabilities and the bootstrap numbers obtained from the Maximum Likelihood analysis

159 (Figure 2, see Supplementary material for ML tree).

160

\section{Automatic species delimitation methods}

ABGD: The analysis proposed two partitions of the dataset, one with 5 clusters (plus the outgroup) (ABGD1 in Figure 2) for prior intraspecific divergences $(\mathrm{P})<0.0048$ and the other with 4 clusters (plus the outgroup) (ABGD2 in Figure 2) for P between 0.0066 and 0.0827 .

bPTP: The analysis determined 4 clusters (plus the outgroup) (PTP in Figure 2) having each a Bayesian probability $>0.97$.

GMYC: The single threshold model was preferred over the null model (single species phylogeny with only coalescent processes; $\mathrm{P}<0.05)$. This model identified $6 \mathrm{ML}$ entities $(95 \%$ confidence interval: 3-20): 5 ML clusters (95\% confidence interval: 2-9) and 1 singleton (the outgroup) (GMYC in Figure 2).

173 robust Bayesian clades.

174 Four well-supported groups could be identified. The most basal one (A in Figure 2; PP

$175=0.9 ; \mathrm{B}=48 ; 0.6 \% \mathrm{p}$-distances intra-group maximum divergence) containing all the

176 specimens from Futuna is separated (9.3\% p-distance from the closest sequence) from the

177 group containing all the others $(\mathrm{PP}=0.97 ; \mathrm{B}=48)$. The second one ( $\mathrm{B}$ in Figure 2; $\mathrm{PP}=1 ; \mathrm{B}$

$178=100 ; 0.6 \%$ p-distances intra-group maximum divergence) clusters the three specimens of $C$.

179 rapaensis from Rapa Island and is sister group (11.1\% p-distance from the closest sequence)

180 to a clade containing the two last ones $(\mathrm{PP}=1 ; \mathrm{B}=79)$, one containing the specimens from

181 Marquesas (Hiva Oa, Ua Pou and Nuku Hiva) (C in Figure 2; PP = 1; B = 99; 0.4\% p-

182 distances intra-group maximum divergence) and another containing specimens from Samoa, 
183 Cook and Society Islands ( $\mathrm{D}$ in Figure 2; $\mathrm{PP}=1 ; \mathrm{B}=99 ; 2.4 \%$ p-distances intra-group

184 maximum divergence), separated by $12.1 \%$ (p-distance between the two the closest

185 sequences). Within clade $\mathrm{D}$, there seems to be a geographical structuration, with the

186 specimens from Samoa all clustered in a well-supported group ( $\mathrm{PP}=1 ; \mathrm{B}=99)$, suggesting a

187 genetic isolation of this population, and considered as a distinct species by two out of the four

188 automatic partitions (Figure 2). Since no clear morphological character could separate these

189 specimens from the others of the Clade D, we chose the conservative approach of considering

190 them both as part the same species.

191 Considering all the molecular analyses, we chose to recognise 4 distinct species in the islands

192 of Polynesia, that we described below.

193

194 (Figure 2 near here)

195

196

\section{Morphological analyses}

197

Measures and observations made on the specimens allowed us to confirm the molecular results in recognising 6 species including 3 new ones: $C$. futunensis n. sp., $C$.

199 marquesensis n. sp., C. tupaia n. sp., C. rapaensis Edmondson, 1935, C. parvirostris De Man, 200 1892, and C. weberi De Man, 1892. No molecular data could be obtained from specimens of C. weberi and C. parvirostris of which only type specimens were examined, but morphological studies allowed us to confidently consider them distinct. The descriptions (or re-descriptions) of the species present in Polynesia, as well as their identification key follow. 


\section{Caridina futunensis n. sp.}

(Figure 3)

212

213 (Figure 3 near here)

214

215 Caridina weberi - Keith and Marquet 2011: 42-43; Mary et al. 2006: 33.

216

217

Material examined

218

Type material. Holotype: 1 q ovig, cl 2.8 mm, 14 October 2004, 14²17.278’'S 17809.037’ W,

219 Leava river, Futuna, altitude 97m, G. Marquet, P. Keith \& N. Mary coll., MNHN-IU-2018-

220195 (DNA: CA2118).

221 Paratypes: 1 ovig, cl $2.6 \mathrm{~mm}$, same data as for holotype, MNHN-IU-2018-208 (DNA:

222 CA2119); 1 q ovig, cl 2.9 mm, same data as for holotype, MNHN-IU-2018-209 (DNA:

223 CA2116); 1 o ovig, cl $3.1 \mathrm{~mm}$, same data as for holotype, MNHN-IU-2017-1460 (DNA:

224 CA2032); 1 q ovig, $3.1 \mathrm{~mm}$, same data as for holotype, MNHN-IU-2017-64 (DNA:

225 CA2117); 1 q, cl $3.0 \mathrm{~mm}$, same data as for holotype, MNHN-IU-2017-1459 (DNA:

226 CA2031); 1 ㅇ, cl $3.6 \mathrm{~mm}, 12$ October $2004,4^{\circ} 17.738^{\prime} \mathrm{S} 178^{\circ} 08.423^{\prime} \mathrm{W}$, Vainifao river,

227 Futuna, altitude 150m, G. Marquet, P. Keith \& N. Mary coll., MNHN-IU-2017-65 (DNA:

228 CA2033).

229

230 Comparative material. Type material

231 Caridina parvirostris De Man, 1892. 
232 Syntypes: 2 ㅇ, cl. 3.1-3.2 mm, river near Bombang, Flores Island, Indonesia, M. Weber coll.,

233 MNHN-IU-2015-1748; 1 , cl. 4.2 mm, same data as for previous, MNHN-IU-2015-1754.

234 Caridina weberi De Man, 1892.

235 Syntypes: 2 ふै, cl 4.4-4.5 mm and 1 ovig, cl $6.1 \mathrm{~mm}$, Kotting, Flores Island, Indonesia, M.

236 Weber coll., MNHN-IU-2015-1755.

Description

Cephalothorax. Rostrum (Figures 3h and 7F): always bent down, short, 0.2-0.3 of cl,

240 reaching to base of first segment of antennular peduncle, armed dorsally with 5-10 teeth, 0 of 241 them on carapace posterior to orbital margin, ventral margin with $0-3$ teeth. Rostrum formula

242 (0) 5-10/0-3. Suborbital angle indistinguishably fused with antennal spine. Pterygostomian 243 margin rectangularly rounded..

244 Eyes well developed, anterior end reaching to 0.73 length of antennular peduncle basal 245 segment. Antennular peduncle 0.47 times as long as carapace. Anterolateral angle reaching 2460.20 length of second segment, second segment subequal to third. Stylocerite reaching to 0.90 247 length of antennular peduncle basal segment. Scaphocerite distincly overreaching tip of 248 antennular peduncle, about 2.1 times longer than wide.

249 Mouthparts. Left mandible, right mandible, first maxilla, second maxilla, first maxilliped, 250 second maxilliped and third maxilliped typical of genus.

251 Pereiopods. Epipods on first four pereiopods.

252 Pereiopod 1 (Figure 3a): chela about 1.9-2.2 times as long as wide, movable finger 2.3-2.9

253 times as long as wide, $0.7-1.0$ times length of palm, carpus $1.3-1.5$ times as long as wide.

254 Pereiopod 2 (Figure 3b) More slender and longer than first pereiopod with chela 2.4-2.6 times 255 as long as wide: movable finger 4.0-5.0 times as long as wide, 1.5-1.9 times length of palm, 256 carpus slender 5.5-6.2 times as long as wide. 
Pereiopod 3 (Figure 3c, e): stout, dactylus 2.6-3.9 times as long as wide (terminal spine

258 included) with 5 spines on flexor margin including terminal spine, propodus 8.8-13.1 times as 259 long as wide, 3.7-4.5 times as long as dactylus.

260 Pereiopod 5 (Figure 3d, f): dactylus 2.9-3.7 as long as wide with 25-38 spiniform setae on 261 flexor margin, propodus 12.2-13.8 times as long as wide, 4.3-4.9 times as long as dactylus. 262 Abdomen. Third abdominal somite with moderately convex dorsal profile. Sixth abdominal 263 somite about 0.5 of carapace length, 1.3 times as long as fifth somite, shorter than telson. 264 Telson (Figure 3k) 2 times as long as wide, with four to six pairs of dorsal spinules and one 265 pair of dorsolateral spinules, posterior margin with median process, rounded with 5 266 intermediate plumose setae longer than lateral spines.

267 First male pleopod: Unknown (no males in the collections).

268 Second male pleopod: Unknown (no males in the collections).

269 Preanal carina (Figure 3g): High, unarmed.

270 Uropodal diaeresis (Figure 3j) with 17-22 spinules.

271 Eggs (Figure 3i): Size 0.43-0.53 × 0.25-0.30mm.

272

273 Habitat (Figure 7G)

This new species prefers fresh and well-oxygenated running waters from the lower 275 course to the higher course.

276

277 Etymology

278 This new species is named futunensis, from the name of the island, Futuna, where this 279 new species occurs. 
Distribution (Figure 8)

This species is known only from Futuna so far and seems to be endemic.

Remarks

This species looks like $C$. parvirostris by its bent rostrum with 5-10 dorsal teeth and no post orbital teeth (vs bent rostrum with 8-10 dorsal teeth and no postorbital teeth in $C$. parvirostris) but the $\mathrm{P} 2$ carpus is shorter 5.5-6.2 times as long as wide (vs 6.0-7.4 in $C$. parvirostris) and so is P2 chela 2.4-2.6 times as long as wide (vs 2.6-3.0 in C. parvirostris). This species differs from C. marquesensis n. sp. and C. tupaia n. sp. by its shorter rostrum 0.2-0.3 of cl (vs 0.3-0.4 in C. marquesensis n. sp. and C. tupaia n. sp.), fewer dorsal teeth on the rostrum 5-10 (vs 10-13 in C. marquesensis n. sp. and 8-14 in C. tupaia n. sp.) and P5 dactylus with fewer spiniform setae on flexor margin 25-38 spines (vs 32-55 in $C$. marquesensis n. sp. and 29-54 in C. tupaia n. sp.) and by its telson with 5 intermediate setae longer than lateral spines (vs 6-14 in C. marquesensis n. sp. and 6-10 in C. tupaia n. sp.). (vs one large claw in C. rapaensis). 
308 Caridina weberi - Edmondson 1935: 10, fig. 4h; Adamson 1935: 16; 1939: 36; Marquet 1988 309 (partim); 1991: 129-130 (partim); Poupin 1998: 9 (partim); Keith \& Vigneux 2002: 126 310 (partim), photo $7 \&$ 8; Keith et al. 2002: 44-45 (partim); 2013: 84-85 (partim).

Material examined

313 Type material. Holotype: 1 §̊, cl 2.9 mm, 9 October 2017, 0949.750'S $135^{\circ} 04.418^{\prime} \mathrm{W}$, Ta'ooa 314 river, Hiva Oa Island, French Polynesia, altitude 220m, G. Marquet, P. Tiberghien, E. 315 Feunteun, P. Gerbeaux \& M. Gerbeaux coll., MNHN-IU-2017-66.

316 Paratypes: 1 ovig, cl 3.3 mm, same data as holotype, MNHN-IU-2017-67 (DNA: CA2067); 3171 \% , cl $2.8 \mathrm{~mm}$, same data as holotype, MNHN-IU-2017-68 (DNA: CA2066); 1 o ovig, cl 4.7 $318 \mathrm{~mm}, 18$ October $2017,08^{\circ} 51.126^{\prime} \mathrm{S} 140^{\circ} 06.066^{\prime} \mathrm{W}$, Taipivai river, Nuku Hiva Island, French 319 Polynesia, altitude 130m, G. Marquet, P. Tiberghien, P. Keith \& H. Lucien-Brun coll., 320 MNHN-IU-2017-69 (DNA: CA2075); 1 q ovig, cl 4.8mm, same data as previous, MNHNIU-2017-70 (DNA: CA2074); 1 \%, cl 3.2 mm, 14 October 2017, 09²5.452'S 14003.409'W, 322 unnamed rivulet, Ua Pou Island, French Polynesia, altitude 130m, G. Marquet, P. Tiberghien, 323 P. Keith \& H. Lucien-Brun coll., MNHN-IU-2017-71 (DNA: CA2071); 1 q, cl 3.4 mm, same data as previous, MNHN-IU-2018-257 (DNA: CA2070); 1 ovig, cl 5.2 mm, 21 February $2000,0^{\circ} 24.180^{\prime} \mathrm{S} 140^{\circ} 03.060^{\prime} \mathrm{W}$, Paaumea river, Ua Pou Island, French Polynesia, altitude 326 200m, P. Keith \& E. Vigneux coll., MNHN-IU-2018-258; 1 \&, cl 4.6 mm, same data as 327 previous, MNHN-IU-2018-259.

Comparative material. Type material

$330 \quad$ Caridina weberi De Man, 1892. 


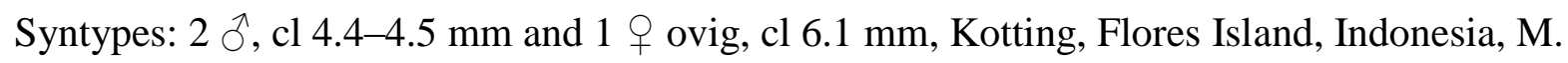

332 Weber coll., MNHN-IU-2015-1755.

\section{Description}

Cephalothorax. Rostrum (Figure 4h): always bent down, short, 0.3-0.4 of cl, reaching to base 336 or middle of second segment of antennular peduncle, armed dorsally with 10-13 teeth, 0-3 teeth on carapace posterior to orbital margin (mostly 2-3), ventral margin with 0-3 teeth. Rostral formula (0-3) 10-13/0-3. Suborbital angle indistinguishably fused with antennular

339 tooth. Pterygostomian margin rectangularly rounded.

340 Eyes well developed, anterior end reaching to 0.62 length of antennular peduncle basal 341 segment. Antennular peduncle 0.50 times as long as carapace. Anterolateral angle reaching 3420.20 length of second segment, second segment subequal to third. Stylocerite reaching to 0.9 343 length of antennular peduncle basal segment. Scaphocerite reaches just slightly beyond tip of 344 antennular peduncle, about 2.1 times longer than wide.

345 Mouthparts. Left mandible, right mandible, first maxilla, second maxilla, first maxilliped, 346 second maxilliped and third maxilliped typical of genus.

347 Pereiopods. Epipods on first four pereiopods.

348 Pereiopod 1 (Figure 4a): chela about 2.0-2.2 times as long as wide, movable finger 2.2-3.1

349 times as long as wide, $0.6-0.9$ times length of palm, carpus 1.3-1.7 times as long as wide. 350 Tips of both fingers with prominent claws (Figure 4b).

351 Pereiopod 2 (Figure 4c) more slender and long than first pereiopod with chela 2.5-3.3 times 352 as long as wide: movable finger 4.2-5.2 times as long as wide, 1.5-1.8 times length of palm, carpus slender 5.5-6.6 times as long as wide. 
Pereiopod 3 (Figure 4d, g): stout, dactylus 2.7-3.1 times as long as wide including terminal

355 spine) with 6-7 spines including terminal spine, propodus with numerous spines on ventral margin, 8.0-9.3 times as long as wide, 3.4-4.3 times as long as dactylus.

Pereiopod 5 (Figure 4e, f): dactylus 3.4-5.5 as long as wide, ending in two large claws with 32-55 spiniform setae on flexor margin, propodus $13.0-17.7$ times as long as wide, 3.8-5.2 times as long as dactylus.

Abdomen. Third abdominal somite with moderately convex dorsal profile. Sixth abdominal somite about 0.37 of carapace, 0.7 times as long as fifth somite, shorter than telson. Telson (Figure 4l) 2.1 times as long as wide, with four to six pairs of dorsal spines and one pair of dorsolateral spines, posterior margin with a median process, rounded with 6-14 intermediate plumose setae longer than lateral spines.

First male pleopod (Figure 4m): Endopod extending to half length of exopod, elongate, with a developed appendix interna near distal end of endopod.

Second male pleopod (Figure 4n): Appendix masculina reaching 0.72 times length of endopod, appendix interna reaching about 0.50 times appendix masculina length.

Preanal carina (Figure 4i): High, unarmed.

Uropodal diaeresis (Figure 4k): with 16-22 spinules.

Eggs (Figure 4j): Size 0.39-0.47 × 0.23-0. 27mm.

\section{Habitat}

This new species prefers fresh and well-oxygenated running waters from the lower course to the higher course. In Nuku Hiva (Marquesas islands) C. marquesensis n. sp. lives in lentic habitat of the lower course, associated with accumulations of leaves, where it collects small detritus and eventually is able to swim (Fossati et al. 2002). 
Etymology

This new species is named marquesensis, from the name of the archipelago,

381 Marquesas Islands, where it occurs.

382

383

Colour pattern (Figure 7C)

The live general colour of the body is bluish to greenish and slightly translucent.

Numerous red spots are visible all over the body.

Distribution (Figure 8)

This species is known only from Marquesas islands (Nuku Hiva, Hiva Oa, Ua Pou

Islands) so far and seems to be endemic.

Remarks

This new species was identified as C. weberi several times: Edmondson (1935),

393 Adamson (1935, 1939), Marquet (1988), Marquet (1991), Poupin (1998), Keith \& Vigneux

394 (2002), Keith et al. (2002), Keith et al. (2013). Indeed this species looks like C. weberi sensu

395 stricto by its straight or bent down rostrum, $0.3-0.4$ of $\mathrm{cl}$, (vs 0.4 in $C$. weberi) reaching to the

396 base or middle of second segment of antennular peduncle with numerous dorsal teeth 10-13

397 (vs 10-19 in C. weberi), but differs by the presence of 0-3 dorsal teeth situated on carapace

398 behind orbital margin (vs 0 in C. weberi). Also its P1 movable finger is shorter 0.6-0.9 times

399 length of palm (vs 1.2-1.3 in C. weberi) as is its P1 carpus 1.3-1.7 times as long as wide (vs

$400 \quad 1.9-2.0$ in $C$. weberi), and its P2 carpus is longer, 5.5-6.6 times as long as wide (vs 4.9-5.0 in

401 C. weberi). Furthermore, the posterior margin of the telson always shows only one pair of

402 lateral spines (vs 2 in C. weberi). 
404 carapace posterior to orbital margin (vs mostly 0 in $C$. tupaia $\mathrm{n}$. sp.), its tips of both P1 fingers with prominent claws (vs not in C. tupaia n. sp.) and its P5 dactylus ending in two large claws (vs one claw in C. tupaia n. sp.).

\section{Caridina tupaia n. sp.}

(Figure 5)

(Figure 5 near here)

Caridina weberi - Edmondson 1935 : 8-9, fig. 3 (a-f) page 11, fig. 4g page 13; Marquet 1988 (partim); 1991: 129-130 (partim); Poupin 1998: 9 (partim); Keith \& Vigneux 2002: 126 (partim), Keith et al. 2002: 44-45 (partim); 2013: 84-85 (partim).

Caridina cf. weberi - Page et al. 2007b: specimen voucher GU-993, sequence DQ478493.

Caridina cf. weberi sp. 3 - Mazancourt et al. 2018.

\section{Material examined}

Type material. Holotype: 1 , cl 4.1 mm, 23 October $2017,17^{\circ} 49.719^{\prime} \mathrm{S} 149^{\circ} 17.067^{\prime} \mathrm{W}$, Papehere river, Tahiti Island, French Polynesia, G. Marquet \& P. Tiberghien coll., MNHNIU-2018-260 (DNA: CA2058).

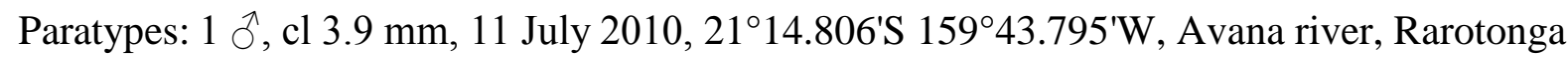
Island, Cook Islands, altitude 5-10m, P. Keith, P. Gerbeaux \& G. Marquet coll., MNHN-IU2018-261 (DNA: CA1048); 1 §, cl 4.1 mm, same data as previous, MNHN-IU-2018-262 (DNA: CA1046); 1 §ै, cl 4.2 mm, same data as previous, MNHN-IU-2018-263 (DNA: CA1047); 1 q ovig, cl $3.8 \mathrm{~mm}$, same data as previous, MNHN-IU-2018-264 (DNA: 


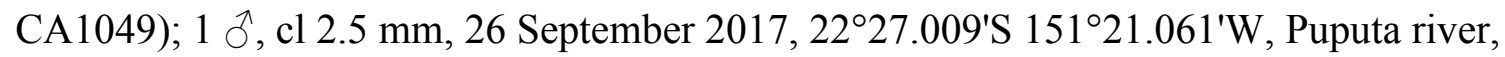
Rurutu Island, French Polynesia, G. Marquet \& P. Tiberghien coll., MNHN-IU-2018-265 (DNA: CA2054); 1 \%, cl 3.5 mm, same data as previous, MNHN-IU-2018-266 (DNA:

CA2055); 1 , cl 4.1 mm, same data as holotype, MNHN-IU-2018-267 (DNA: CA2059); 1 ㅇ ovig, cl 4.2 mm, 1 July 2001, Mahidi river, Huahiné Island, French Polynesia, P. Keith \& E. Vigneux coll., MNHN-IU-2018-268; 1 , , cl 4.5 mm, same data as previous, MNHN-IU2018-269; 1 ㅇ, cl 2.8 mm, 5 October 2017, 17³2.785'S 14948.484'W, Afareaitu river, Moorea Island, French Polynesia, altitude 109m, G. Marquet \& P. Tiberghien coll., MNHNIU-2018-270 (DNA: CA2062); 1 q ovig, cl 3.9 mm, same data as previous, MNHN-IU-201611762 (DNA: CA2063); 1 q ovig, cl 6.2 mm, 10 July 2014, 1354.543'S 171³5.300'W, Falefa river, Upolu Island, Samoa, altitude <50m, P. Gerbeaux coll., MNHN-IU-2016-11763 (DNA: CA1410); 1 q ovig, cl 5.5 mm, 8 July 2014, 1353.642'S 171³9.913'W, Tuafaleloa river, Upolu Island, Samoa, altitude 100m, P. Gerbeaux coll., MNHN-IU-2016-11764 (DNA:

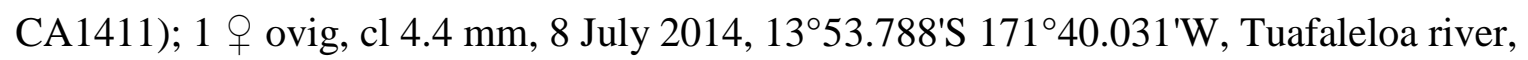
Upolu Island, Samoa, altitude 250m, P. Gerbeaux coll., MNHN-IU-2016-11765 (DNA: CA1412); 1 ㅇ, cl 5.0 mm, 12 July $2014,13^{\circ} 43.741^{\prime} \mathrm{S} 172^{\circ} 18.832^{\prime} \mathrm{W}$, Faleata river, Savaii Island, Samoa, altitude 195m, P. Gerbeaux coll., MNHN-IU-2016-11766 (DNA: CA1413); 1

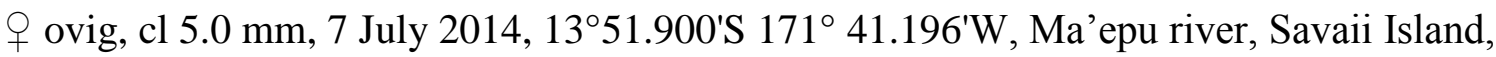
Samoa, altitude 20-50m, P. Gerbeaux coll., MNHN-IU-2016-11767 (DNA: CA1918).

\section{Comparative material. Type material}

Caridina weberi De Man, 1892.

Syntypes: 2 ○े, cl 4.4-4.5 mm and 1 q ovig, cl $6.1 \mathrm{~mm}$, Kotting, Flores Island, Indonesia, M. Weber coll., MNHN-IU-2015-1755. 
454 Cephalothorax. Rostrum (Figure 5g): rarely straight, mostly bent down, short, 0.3-0.4 of cl, 455 reaching to base or middle of second segment of antennular peduncle, armed dorsally with 8 45614 teeth, $0-3$ of them situated on carapace posterior to orbital margin (mostly 0), ventral 457 margin with 1-3 teeth. Rostral formula (0-3) 8-14/1-3. Suborbital angle indistinguishably 458 fused with antennular tooth. Pterygostomian margin rectangularly rounded.

459 Eyes well developed, anterior end reaching to 0.77 length of antennular peduncle basal 460 segment. Antennular peduncle 0.55 times as long as carapace. Anterolateral angle of basal segment reaching 0.20 length of second segment, second segment twice as long as third. Stylocerite reaching to 0.90 length of antennular peduncle basal segment. Scaphocerite reaching just slightly beyond the tip of antennular peduncle, about 3 times longer than wide. Mouthparts. Left mandible, right mandible, first maxilla, second maxilla, first maxilliped, second maxilliped and third maxilliped typical of genus. Pereiopods. Epipods on first four pereiopods.

467 Pereiopod 1 (Figure 5a): chela about 1.9-2.1 times as long as wide, movable finger 2.2-3.3 468 times as long as wide, 0.71 .0 times length of palm, carpus 1.3-1.7 times as long as wide. 469 Pereiopod 2 (Figure 5b) more slender and longer than first pereiopod with chela 2.4-2.8 times as long as wide: movable finger 3.8-4.9 times as long as wide, 1.3-1.7 times length of palm, 471 carpus slender 4.7-6.1 times as long as wide.

472 Pereiopod 3 (Figure 5c, f): stout, dactylus 2.6-4.2 times as long as wide including terminal 473 spine with 5-7 spines including terminal spine, propodus with numerous spines on ventral 474 margin, 7.6-10.6 times as long as wide, 3.4-5.2 times as long as dactylus.

475 Pereiopod 5 (Figure 5d, e): dactylus 3.5-4.7 times as long as wide with 29-54 spiniform setae 476 on flexor margin, propodus 11.6-16.0 times as long as wide, 3.7-4.4 times as long as 477 dactylus. 
Abdomen. Third abdominal somite with moderarely convex dorsal profile. Sixth abdominal somite about 0.46 times carapace length, as long as fifth somite, shorter than telson. Telson (Figure 5k): 2.3 times as long as wide, with four or five pairs of dorsal spines and one pair of dorsolateral spines, posterior margin with median process, rounded with 6-10 intermediate 482 plumose setae longer than lateral spines.

483 First male pleopod (Figure 51): Endopod extending to half length of exopod, elongate, with 484 developed appendix interna near distal end of endopod.

485 Second male pleopod (Figure 5m): Appendix masculina reaching 0.68 times length of endopod, appendix interna reaching about 0.40 times appendix masculina length Preanal carina (Figure 5h): High, unarmed.

Uropodal diaeresis (Fig.5j): With 16-20 spinules.

Eggs (Figure 5i): Size $0.38-0.47 \times 0.20-0.30 \mathrm{~mm}$.

\section{Habitat}

This new species prefers fresh and well-oxygenated running waters from the lower course to the higher courses. Under the name of $C$. weberi, its microhabitat was intensely studied in Opunohu river (Moorea) with that of another sympatric species Atyoida pilipes (Newport, 1847) (Resh et al. 1990). C. tupaia n. sp. were often found near leaf litter, tending to aggregate in on the bottom of pools where detritus accumulated. Both their leaf litter habitat and their ability to consume it in the laboratory indicate the possibility that this scraper

498 increase rates of litter decomposition (Williams 1999). Cheliped morphology and,

499 consequently, differences in feeding methods are the main factors determining the 500 microdistribution of A. pilipes and C. tupaia. A. pilipes is filter feeding in faster flowing 501 habitats, while C. tupaia are scraping and sweeping detritus within and on leaf surfaces and 502 also in other microhabiats on the stream channel bed (Resh et al. 1990). C. tupaia, whose 
microhabitat is in pools and slow water, may be less able to grasp the substrate in high

504 velocity water, while A. pilipes which is often found in the faster moving water of riffles may

505 be better able to grasp the substrate (Feldman 1996). These differences are likely a

506 contributing factor in their distribution above and below barriers such as waterfalls and

507 culverts, which require fighting current to move farther upstream. The climbing ability of

508 these two species was tested by Falvo (2013) in rivers of Moorea (Opunohu and Afareaitu).

509 C. tupaia had the highest success rate and A. pilipes was the fastest climber. The latter species

510 is found at higher reaches of the streams than C. tupaia. These species exhibited different

511 climbing behaviours. C. tupaia would consistently take breaks while climbing, only moving a

512 few centimetres at a time, while A. pilipes would rarely stop once it started climbing. An

513 examination of the distal portions of the pereiopods of $A$. pilipes and C. tupaia indicates that

514 A. pilipes is more strongly built and its appendages may also be better suited for gripping

515 substrate and with standing current, explaining its ability to reach higher altitudes.

Etymology

This new species is named in honour of Tupaia, the Polynesian pilot of James Cook,

519 on board of H.M.S. Endeavour for its ability to cross long distances between Polynesian 520 islands.

Colour pattern (Figure 7A, B) red spots are visible all over the body. Sometimes, a lighter longitudinal dorsal band is present stretching from the rostrum to the telson. 
Among the species studied here, this species seems to have the widest distribution in

529 Polynesia (Upolu, Savaii (Samoa), Rarotonga (Cook Islands), Rurutu, Tahiti, Moorea, and

530 Huahine (French Polynesia)).

Remarks

This new species was identified as C. weberi several times: Edmondson (1935),

534 Adamson (1935, 1939), Marquet (1988), Marquet (1991), Poupin (1998), Keith and Vigneux 535 (2002), Keith et al. (2002), Page et al. (2007b), Keith et al. (2013). Indeed this species looks

536 like $C$. weberi sensu stricto by its straight or bent down rostrum, $0.3-0.4$ of cl, (vs 0.4 in $C$.

537 weberi) reaching to the base or middle of second segment of antennular peduncle with

538 numerous dorsal teeth $8-14$ (vs 10-19 in C. weberi), but differs by the presence of 0-3 dorsal

539 teeth situated on carapace behind orbital margin (vs 0 in C. weberi). Also its P1 movable

540 finger is shorter $0.7-1.0$ times length of palm (vs 1.2-1.3 in C. weberi) as is its P1 carpus 1.3-

$541 \quad 1.7$ times as long as wide (vs 1.9-2.0 in C. weberi). Furthermore, the posterior margin of the

542 telson shows always only one pair of lateral spines (vs 2 in C. weberi).

543 This species is easily separated from C. marquesensis n. sp. by numerous characters

544 (see previously).

(Figure 6 near here) 
553

554 Poupin 1998: 8; Keith \& Vigneux 2002: 125, photo 3 \& 4; Keith et al. 2002: 40-41; 2013:

$555 \quad 78-79$.

556

557

558

559

560

561

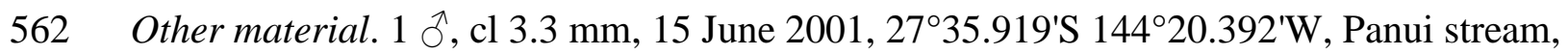

563 Rapa Island, French Polynesia, altitude 18m, G. Marquet coll., MNHN-IU-2016-11768; 1 ○, $564 \mathrm{cl} 3.4 \mathrm{~mm}$, same data as previous, MNHN-IU-2016-11769 (DNA: CA2114); 1 q, cl $4.8 \mathrm{~mm}$, 565 same data as previous, MNHN-IU-2016-11770; 1 \% , cl $5.2 \mathrm{~mm}$, same data as previous,

\section{Material observed}

Type material. Holotype: 1 †, cl 4.7 mm, 1934, a freshwater stream, Rapa Island, French Polynesia, Mangarevan Expedition coll., BPBM 53933.

Paratype: 1 \&, cl $5.0 \mathrm{~mm}$, same data as holotype, BPBM 53694. MNHN-IU-2016-11771 (DNA: CA2115); 1 q, cl 6.0 mm, same data as previous, MNHN-IU2016-11772 (DNA: CA2111); 2 ふ, cl 2.5-2.9 mm and 2 † ovig, cl 4.0-4.6 mm, 2 May 1986, $22^{\circ} 26.240$ 'S $151^{\circ} 22.243^{\prime} \mathrm{W}$, Tevaovai stream, Rurutu Island, French Polynesia, altitude 52m, G. Marquet coll., MNHN-IU-2015-1921.

Comparative material. Type material

Caridina parvirostris De Man, 1892.

Syntypes: 2 †, cl. 3.1-3.2 mm, river near Bombang, Flores Island, Indonesia, M. Weber coll., MNHN-IU-2015-1748; 1 q, cl. 4.2 mm, same data as for previous, MNHN-IU-2015-1754.

\section{Caridina weberi var. keiensis Roux, 1911}

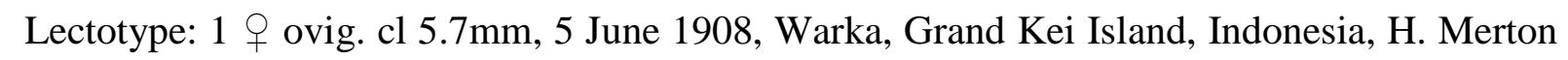
coll., NMB 6.IV.b. 


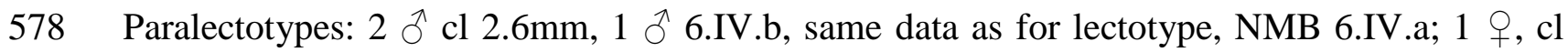

$5795.5 \mathrm{~mm}$ and $1 \hat{\jmath}, \mathrm{cl} 3.4 \mathrm{~mm}$, same data as for lectotype, NMB 6.IV.b.

$580 \quad$ Caridina weberi De Man, 1892.

581 Syntypes: 2 ふै, cl 4.4-4.5 mm and 1 o ovig, cl $6.1 \mathrm{~mm}$, Kotting, Flores Island, Indonesia, M.

582 Weber coll., MNHN-IU-2015-1755.

583

584 Description

585 Cephalothorax. Rostrum (Figure 6h): always bent down, short, $0.3-0.5$ of cl, reaching to base

586 of second segment of antennular peduncle, armed dorsally with 0-5 teeth, occupying distal

587 fourth of border, none situated on carapace posterior to orbital margin, ventral margin with 1-

5886 teeth. Rostral formula (0) 0-5/1-6. Suborbital angle indistinguishably fused with antennular

589 tooth. Pterygostomian margin rounded.

590 Eyes well developed, anterior end reaching to 0.77 length of antennular peduncle basal

591 segment. Antennular peduncle 0.44 times as long as carapace. Anterolateral angle of basal

592 antennular segment reaching 0.20 length of second antennular segment, second antennular

593 segment distinctly longer than third. Stylocerite reaching to end of antennular peduncle basal

594 segment. Scaphocerite reaching just slightly beyond tip of antennular peduncle, about 3.1

595 times longer than wide.

596 Mouthparts. Left mandible, right mandible, first maxilla, second maxilla, first maxilliped,

597 second maxilliped and third maxilliped typical of genus.

598 Pereiopods. Epipods on first four pereiopods.

599 Pereiopod 1 (Figure 6a): chela about 1.5-2.5 times as long as wide, movable finger 1.5-4.4

600 times as long as wide, 0.5-1.4 times length of palm, carpus 1.2-1.7 times as long as wide.

601 Tips of both fingers with prominent claws (Figure 6b). 
602 Pereiopod 2 (Figure 6c): more slender and long than first pereiopod with chela 2.0-2.7 times

603 as long as wide: movable finger 3.2-4.7 times as long as wide, 1.3-1.9 times length of palm,

604 carpus slender 4.2-5.2 times as long as wide.

605 Pereiopod 3 (Figure 6d, g): stout, dactylus 2.7-3.9 times as long as wide including terminal

606 spine with 6-8 spines including terminal spine, propodus 9.0-12.8 times as long as wide, 3.9-

6074.9 times as long as dactylus.

608 Pereiopod 5 (Figure 6e, f): dactylus 3.1-4.9 as long as wide, ending in two large claws with $609 \quad 30-45$ spiniform setae on flexor margin, propodus $11.7-19.0$ times as long as wide, with

610 numerous spines on ventral margin, 4.5-5.4 times as long as dactylus.

611 Abdomen. Third abdominal somite with moderarely convex dorsal profile. Sixth abdominal 612 somite about 0.4 times carapace length, 1.2 times as long as fifth somite, shorter than telson.

613 Telson (Figure 6k): 2.9 times as long as wide, with five or six pairs of dorsal spines and one 614 pair of dorsolateral spines, posterior margin with small median process, rounded with 5-13

615 intermediate plumose setae much longer than lateral spines.

616 First male pleopod (Figure 6m): Endopod extending to 0.42 times length of exopod,

617 rectangular, with a short appendix interna near distal end of endopod.

618 Second male pleopod (Figure 6n): Appendix masculina reaching 0.83 times length of

619 endopod, appendix interna reaching about 0.34 times appendix masculina length

620 Preanal carina (Figure 6i): High, unarmed.

621 Uropodal diaeresis (Figure 6k): with 15-20 spinules.

622 Eggs (Figure 6j): Size 0.44-0.49 × 0.26-0.29mm.

623

Habitat

This new species prefers fresh and well-oxygenated running waters from the lower

626 course to the middle course. 
628 Colour pattern (Figure 7D, E)

The live general colour of the body is yellowish to greenish and slightly translucent.

630 Numerous red spots are visible all over the body.

631

632 Distribution (Figure 8)

633 This species is known only from Austral Islands (Rurutu and Rapa islands) so far and 634 seems to be endemic.

635

Remarks

Our specimens look like those described by Edmondson (1935): Rostrum always bent 638 down, short, $0.3-0.5$ of $\mathrm{cl}$, reaching to base of second segment of of antennular peduncle (vs 639 rostrum slender, slightly turned down, reaching to the middle of the second segment of the 640 antennular peduncle for Edmondson (1935)), rostrum armed with 0-5 teeth on dorsal margin, 641 occupying the distal fourth of the border, ventral margin with 1-6 teeth. (vs rostral teeth small 642 and few, stronger above than below, those above occupying the distal fourth of the border, the 643 first (basal) tooth below being posterior to the first one of the upper border for Edmondson 644 (1935)), P1 finger 0.5-1.4 times length of palm (vs dactylus as long as upper border of palm 645 for Edmondson (1935)), P3 dactylus with 6-8 spines on flexor margin in addition to the 646 terminal spine (vs border dactylus provided with a stout tooth just proximal of the tip, and 647 four other small spines for Edmondson (1935)), P5 dactylus ending in two large claws with $648 \quad 30-45$ spiniform setae on flexor margin (vs dactylus of fifth leg bearing numerous short hairs 649 and a strong supplementary tooth near the tip for Edmondson (1935)), posterior margin of the 650 telson with a little median process, rounded with 5-13 intermediate plumose setae much 651 longer than lateral spines (vs telson with 6 pairs of small spines on upper border, its posterior 
652

653

654

655

656

657

658

659

660

661

662

663

664

665

666

667

668

669

670

671

672

673

674

675

(Figure 7 near here)

margin bearing a small median tooth for Edmondson (1935)), and uropodal diaeresis with 1520 spinules (vs uropodal spinelets 20 in number for Edmondson (1935)).

This species differs from $C$. parvirostris by its bent rostrum with fewer dorsal teeth

(0-5) (vs bent rostrum with 8-10 dorsal teeth in C. parvirostris) and its $\mathrm{P} 2$ carpus shorter $4.2-$ 5.2 times as long as wide (vs 6.0-7.4 in C. parvirostris) and so is P2 chela 2.0-2.7 times as long as wide (vs 2.6-3.0 in C. parvirostris).

This species differs from $C$. futunensis n. sp. by its bent rostrum with fewer dorsal teeth (0-5) (vs bent rostrum with 5-10 in C. futunensis n. sp.) and its P5 dactylus ending in two large claws (vs one large claw in $C$. futunensis n. sp.).

C. rapaensis was reported by Shokita (2003) from Ryukyu Islands, but according to Cai and Shokita (2006), these specimens actually belong to C. prashadi Tiwari \& Pilai, 1971 described from the Andaman Islands. Indeed, even if the rostrum formula is similar (0) 0 5/1-6 (vs (0)1-6/3-6 in C. prashadi), C. rapaensis can be distinguished easily from $C$. prashadi by its prominent claws on the tips of both $\mathrm{P} 1$ fingers (vs no prominent claws in $C$. prashadi) and by its P5 dactylus ending in two large claws (vs one claw in C. prashadi) with 30-45 spiniform setae on flexor margin (vs 29 in C. prashadi).

C. rapaensis looks like $C$. weberi var. keiensis from Kei Islands (Indonesia) by its bent and short rostrum, its P1 chela bearing prominent claws and its P5 dactylus being biunguiculate. However, they can be distinguished by the number of dorsal teeth on the rostrum 0-5 (vs 2-13 in C. weberi var. keiensis). Furthermore, considering the distance between Kei Islands and Polynesia and that $C$. weberi var. keiensis has never been collected in between, we consider it to be a distinct species.

676 
678 1. Rostrum armed dorsally with many teeth (10-19), relatively long (0.3-0.4 of cl, reaching to

679 base or middle of antennular peduncle second segment)......

680 - Rostrum armed dorsally with few teeth (0-10), mostly relatively short $(0.2-0.3$ of cl,

681 reaching to end of antennular peduncle basal segment). 3

682

6832 Mostly 2-3 dorsal rostrum teeth situated on carapace behind orbital margin, tips of both P1

684 fingers with prominent claws, P5 dactylus ending in two large

685 claws.

C. marquesensis $\mathrm{n} . \mathrm{sp}$.

686 - Mostly no dorsal rostrum teeth, tips of both P1 fingers without prominent claws, P5 dactylus

687 ending in one large claw.

C. tupaia n. sp.

688

689

3 Rostrum armed dorsally with 5-10 teeth, $0.2-0.3$ of cl, reaching to end of antennular

690 peduncle basal segment, tips of both P1 fingers without prominent claws....C. futunensis n. sp.

691 - Rostrum armed dorsally with 0-5 teeth on dorsal margin, $0.3-0.5$ of cl, reaching to base or

692 middle of antennular peduncle second segment), tips of both P1 fingers with prominent

693 claws

C. rapaensis

694

695 Discussion

696 Systematics

697 The taxonomy of the $C$. weberi complex is problematic because it is based essentially

698 on the rostrum (variable in length and shape) and on teeth (number of dorsal teeth, dorsal

699 teeth situated on carapace behind orbital margin). Curiously, C. weberi is reported from

700 numerous localities in Indonesia, Philippines, Micronesia and Melanesia, but in the literature,

701 put apart specimens described by Bouvier (1925) and Edmondson (1935), only two 
702

703

704

705

706

707

708

709

710

711

712

713

714

715

716

717

718

719

720

721

722

723

724

725

726

publications detailed the morphological characters of this species, the first one by Roux (1928), and the second one by Cai and Ng (2001). Specimens from Ceram (Indonesia) described as $C$. weberi by Roux (1928) look like our specimens of $C$. tupaia n. sp. by its P1 chela about 1.9-2.1 times as long as wide (vs 2-2.2 in C. tupaia n. sp.), P1 movable finger 0.7-1.0 times length of palm; (vs 0.9-1.2 in C. tupaia n. sp.), its P2 carpus slender 4.7-6.1 times as long as wide (vs 5.5-7.5 in C. tupaia n. sp.), its P3 dactylus 2.6-4.2 times as long as wide (terminal spine included) (vs 3.1-3.8 in C. tupaia n. sp.) with 5-7 spines on flexor margin in addition to the terminal one (vs 6-7 in $C$. tupaia n. sp.), P3 propodus, 3.7-5.2 times as long as dactylus (vs 4.5-5.4 in C. tupaia n. sp.), its P5 dactylus 3.5-4.7 as long as wide (vs 4.4-5.0 in C. tupaia n. sp.) and its P5 propodus 11.6-16.0 times as long as wide (vs 11-15 in C. tupaia n. sp.), but its rostral formula is different: (0-3) 8-14/ 1-3 (vs (0-2)12-19/2-6 in C. tupaia $\mathrm{n} . \mathrm{sp}$.$) , its P1 carpus is shorter 1.3-1.7 times as long as wide.(vs 1.5-2.1 in C. tupaia \mathrm{n}$. sp.), so is its P2 chela 2.4-2.8 times as long as wide: (vs 2.8-3.1 in C. tupaia n. sp.), and its P3 propodus 7.6-10.7 times as long as wide (vs 11-16 in C. tupaia n. sp.), its P5 dactylus bears fewer spiniform setae on flexor margin 29-54 (vs 62-70 in C. tupaia n. sp.), and finally, its eggs are larger $0.38-0.47 \times 0.20-0.30 \mathrm{~mm}$ (vs $0.35-0.38 \times 0.2-0.21$ in C. tupaia $\mathrm{n}$. sp.). Our specimens of $C$. tupaia n. sp. also look like those from Halmahera described by Cai and $\mathrm{Ng}(2001)$ as $C$. weberi by its rostral formula (0-3) 8-14/1-3 (vs (0-2) 13-14/2-3 for Cai and $\mathrm{Ng}$ (2001)), P1 movable finger 0.7-1.0 times length of palm (vs 1.0 for Cai and $\mathrm{Ng}(2001)$ ), carpus 1.3-1.7 times as long as wide (vs 1.3 for Cai and $\mathrm{Ng}$ (2001)), P5 dactylus with 29-54 spiniform setae on flexor margin (vs 55 for Cai and $\mathrm{Ng}$ (2001)) and P5 propodus 3.7-4.4 times as long as dactylus (vs 5 for Cai and $\mathrm{Ng}(2001)$ ), and its eggs size $0.38-0.47 \times 0.20-0$. $30 \mathrm{~mm}$ (vs $0.4 \times 0.2$ for Cai and $\mathrm{Ng}(2001)$ ). They differ from these specimens by the posterior margin of the telson that always shows one pair of lateral spines (vs 2 for Cai and $\mathrm{Ng}$ (2001); see Figure 3C, D, E, like C. weberi sensu stricto). 
In this complex, as for others, it is necessary to always combine genetics with morphology and to collect specimens from the type locality in order to do a genetic study.

\section{Distribution}

\section{Endemism in the Marquesas and Austral archipelagos, and in Futuna}

The high degree of freshwater endemism is well known in the Marquesas Islands where all the freshwater Gobiidae (Teleostei) are endemic (Keith et al. 2015). There is also one endemic freshwater palaemonid prawn (Macrobrachium feunteuni Keith and Vigneux, 2002) (Keith and Vigneux 2002), one endemic varunid (Decapoda: Brachyura)

Ptychognathus crassimanus Finnegan, 1931 (NK Ng, pers. comm.) and now an endemic Caridina shrimp, C. marquesensis n. sp.. This high rate of endemism is also well known in the Austral archipelago, and particularly in Rapa Island, with its endemic Gobiidae (Teleostei): Sicyopterus rapa Parenti \& Maciolek, 1996 and Stiphodon julieni Keith, Watson \& Marquet, 2002. Stenogobius randalli Watson, 1991 is restricted to Austral archipelago, and Stiphodon discotorquatus Watson, 1995 is restricted to Rarotonga (Cook), Rurutu and Tubuai (Austral Islands). Caridina rapaensis is restricted to Rapa and Rurutu. Compared to Marquesas and Austral archipelagos, Society shows another different type of fauna. The type of life cycle for all native freshwater species in Polynesia is amphidromy. Indeed, river systems are colonised by crustaceans (Palaemonidae and Atyidae) with a life cycle typically adapted to the conditions that prevail in these distinctive insular habitats; i.e, young oligotrophic rivers, subject to extreme climatic and hydrological seasonal variations. These species spawn in freshwater, the free larvae drift downstream to the sea where they undergo a planktonic phase during several days to several months, before returning to the rivers to grow and reproduce. With this type of lifecycle, numerous authors suggest that some oceanic currents are biogeographic genetic barriers (Planes 1993; Mennesson 2016) and so generate 
endemic species. This could partially explain the patterns observed in Marquesas and Austral Islands. There are in our study area (Figure 8) two main currents: the South Equatorial Current (SEC) and the South Equatorial countercurrent (SECC). SEC is caused by the influence of South-East trade winds and flows from east to west. More southward, the SECC flows from West to East. Under the influence of SEC and SECC, a gyre is formed. The global westward trend of the currents in the area could partially explain the distribution of $C$. tupaia n. sp. ranging from Society to Samoa through Cook and Rurutu (Austral) by carrying the larvae that would thus supposedly live in depths within the influence of those surface currents.

In French Polynesia, the Marquesas archipelago (Figure 8) is located in the Marquesas countercurrent (MCC), oriented from West to East. It is very regular throughout the year (Martinez et al. 2009). Tuamotu, Gambier and Society archipelagos are located in the South Equatorial Current (SEC) oriented from Northeast to Southwest. The Austral archipelago is located in the South Equatorial Countercurrent (SECC) oriented from west to east. This climatolological scheme will be of major importance for the establishment of species that have a planktonic dispersive larval phase, such as species of the genus Caridina. Indeed the opposition (Figure 8) between the MCC and the SEC could explain the strong divergence of the Marquesas population, the border between these two currents (current in opposite direction and bodies of water having different characters) constituting a barrier for larvae (Vermeij 1987).

The same schema exists between the SEC and the SECC, explaining the divergence of the Austral population (Figure 8). So the two endemic areas in the north and south of French Polynesia could be explained by their provision of currents but also by their isolation. Indeed, the Marquesas Islands, which are almost exactly in the centre of the Pacific, are very isolated, some 4,828 $\mathrm{km}$ from the nearest American coast, 4,572 km from the western margin of the 
Pacific depression and 1,287 km from the nearest high islands of the Society archipelago. The Marquesas Islands chain (Craig et al. 2001), with the putative hotspot to the southeast, comprises eleven islands from Eiao (average age 5.4 Ma) in the NW, to Fatu Hiva (average age $1.55 \mathrm{Ma}$ ) in the SE. Among all prospected islands of the Austral archipelago, Rurutu is the oldest: $12.8-0.3 \mathrm{Ma}$ (see Craig et al. 2001), and Rapa is relatively young 5.0-4.1 Ma (Craig et al. 2001) but the most isolated (500 km from the nearest island Raivavae). Contrarily to $C$. futunensis n. sp., C. marquesensis n. sp. or $C$. rapaensis, respectively endemic to Futuna, the Marquesas and Austral Islands, C. tupaia n. sp. has a wide distribution in Polynesia: Upolu (Samoa), Rarotonga (Cook Islands), Rurutu, Tahiti, Moorea, and Huahine (French Polynesia). Its larvae are supposedly transported by the southwestward currents of the gyre to colonize these different lineaments and $C$. tupaia $\mathrm{n}$. sp. is likely to have a greater distribution and reach other islands to the West, like Tonga or Melanesia. Genetic studies are in progress on specimens belonging to the $C$. weberi complex from Fiji, New Caledonia, Vanuatu and Solomon Islands. Since $C$. tupaia n. sp. and C. rapaensis occur in sympatry in Rurutu Island but have different distribution areas, there must be biological differences explaining that they are not constrained in the same way by the currents, such as differences in larvae circulation depths between the two species, duration of the marine larval phase, differences in habitat preferences that restrict the distribution. The explication could also be of historical nature, one species having colonised the islands earlier, when the currents and conditions were different than at present, that prevent new species to arrive.

(Figure 8 near here)

Freshwater endemism is well known in Futuna Island with its endemic freshwater Gobiidae (Teleostei) (Keith et al. 2015): Akihito futuna Keith, Marquet and Watson, 2008, 
802

803

804

805

806

807

808

809

810

811 (Figure 9 near here)

Stenogobius keletaona Keith \& Marquet, 2006, and Smilosicyopus sasali (Keith and Marquet, 2005) and with now an endemic Caridina shrimp, C. futunensis n. sp.. This endemism could be explained by the position of this island at the South of Vityaz trench, which would be depending on the geological time - an obstacle to migration of larvae by its depth and by oceanic current variations. Indeed, Futuna (Keith et al. 2013) appeared as strong volcanic activity occurred in the contact zone between the Pacific and the Australian plates, at the South of fossil Vityaz subduction, in the junction area between the Lau and North Fiji basins, near the North Fiji transform zone (Figure 9).

812

813 The absence of Caridina in the Further East and Further North of Polynesia The Marquesas Islands represent the eastern limit in Polynesia of the Caridina weberi complex with the presence of $C$. marquesensis n. sp.. Further east, no species of Caridina occur (see Marquet 1991) as it seems to be absent from Mangareva (Gambier archipelago).

817 Situated 1,600 km from Tahiti (Society archipelago) and 1,060 km from Rapa (Austral 818 archipelago), Mangareva (6.26-5.66 Ma, see Craig et al. 2001), of the Gambier Islands, is a high island with small streams suitable for Caridina species, but none has been found so far

820 (Keith et al. 2013). Further north, the Hawaiian Islands are biogeographically the most 821 isolated in the world being about 3,500 to 4,000 $\mathrm{km}$ from the high islands of the Marquesas 822 archipelago, but no Caridina species occurs in this archipelago. ' $C$. weberi' recorded by 823 Devick (1991) as an introduced species, was a misidentification of Neocaridina denticulata sinensis (Kemp, 1918) (see Englund and Cai 1999). Among the Atyidae, only the genus Atyoida reaches both Mangareva and Hawaii. 

stages (for example Lessios et al. 1999, Teske et al. 2008) and the position of Hawaii within the North Pacific gyre surrounded by westward currents makes it impossible for larvae coming from West Polynesia to reach the archipelago.

According to several authors studying the amphidromous lifecycle of different species,

831 Caridina gracilipes De Man, 1892 (Zhang and Sun 1979), C. gracilirostris De Man, 1892

832 (Thomas et al. 1973; Pillai 1975; Heerbrandt and Lin 2006), C. multidentata Stimpson, 1860

833 from Japan (Hayashi \& Hamano 1984; Nakahara et al. 2005), C. typus H. Milne Edwards,

8341837 from Japan (Nakahara et al. 2005), C. leucosticta Stimpson, 1860 from Japan (Nakahara 835 et al. 2005), and $C$. 'weberi' from India (Chinnaya 1974) we count 6 to 9 larval stages reared 836 in the laboratory in 15 to $25.5 \%$ salt water with a larval development from 9 to 48 days. This 837 short larval duration is related to that of other crustaceans like Macrobrachium species. For 838 example, in Macrobrachium australe (Guérin-Méneville, 1838), Ito et al. (2002) managed to 839 obtain 13 zoeal stages. The completion of the first 12 stages requires 50 to 69 days but the 840 larvae can then survive to 150 days before dying for failing to find the environmental 841 conditions required for their survival. For Macrobrachium Lar (Fabricius, 1798), Atkinson 842 (1977) determined 11 zoeal stages representing a maximum duration of 89 days. Their 843 relatively short larval duration could explain the absence of any Caridina in the far North and

844 East of Polynesia. Indeed it does not allow the larvae to cross great distances from Tahiti or 845 Rapa to Mangareva and from Marquesas islands to Hawaii without islands with permanent 846 streams along their migration in this area of the Central Pacific. On the contrary, only robust 847 crustacean species with supposedly long larval durations were able to reach Mangareva or 848 Hawaii such as in genera Atyoida or Macrobrachium for Mangareva. Furthermore, Central 849 Pacific waters are oligotrophic with little phytoplankton, which does not allow the larvae to 850 get much food. Indeed, situated in $8^{\circ}$ and $12^{\circ}$ of latitude South, Marquesas archipelago still 
851 benefits from a remnant of equatorial wealth ( 2 to $4 \mathrm{mmol} / \mathrm{m}^{3}$ of nitrates) but this effect is

852 completely faded south of $15^{\circ} \mathrm{S}$; the waters of the whole Tuamotu-Society-Austral

853 archipelagos are oligotrophic with nitrate levels lower than $0.2 \mathrm{mmol} / \mathrm{m}^{3}$ (Rougerie and

854 Wauthy 1993).

855 The larval durations of the species studied in this work are unknown but are probably

856 different from one to another, judging from the differences in geographical ranges, with

857 endemic species like C. futunensis n. sp. or C. marquesensis n. sp. having a shorter larval 858 duration (and likely fewer larval stages) than $C$. tupaia $\mathrm{n}$. sp.. It would be interesting to study

859 the larval phases of these species by rearing them in the laboratory in order to clarify these 860 points.

Management and conservation of freshwater crustaceans

This first review of Caridina weberi complex in Polynesia gives us an understanding

864 of how diverse and unique its distribution is, with species having a very restricted distribution (C. futunensis n. sp. for example, endemic to Futuna Island) in contrast to others, more widely

866 distributed (C. tupaia n. sp.). An assessment of the status of freshwater fish in Oceania was

867 made at a Red List workshop held at the IUCN Oceania in September 2011, but crustaceans

868 were not included in this assessment as not enough information is currently available to

869 determine their conservation status. Complementary genetic studies on Palaemonidae and

870 Atyidae in this region could fill this gap. An assessment of the status of freshwater

871 crustaceans in Oceania becomes urgent, particularly for endemic species, by the development

872 of nuisances on this fauna like culverts and fords (that assist with water flow passage across

873 roads), dams (for water supply or electricity generation), weirs (for water abstraction),

874 artificial channels (in urban areas), diversions of rivers by convenience or irrigation. 


\section{Acknowledgements}

Cook Islands: We would like to thank the Office of the Prime Minister of Rarotonga and in particular Teumere Koteka-Heather, D. Charlie and M. Mokoroa for the research permit. We are also grateful to G. MacCormack for the invaluable help he has provided us on the field. We thank also the Te Ipukara Society.

French Polynesia: We especially want to thank J.Y. Meyer of the Research delegation and the mayors of the islands for providins sampling authorizations. We acknowledge for their help on the field: P. Tiberghien, E. Feunteun, P. Gerbeaux, E. Vigneux and H. Lucien-Brun. Futuna: We want to Thank A. Malau, head of the Environment office of Wallis and Futuna, P. Vanai and D. Labrousse for the work for the conservation and the management of biodiversity. We also want to thank the King of the Sigave Kingdom, the King of the Alo Kingdom and the head of the rural economy office from Futuna. Finally we acknowledge for their help on the field: Besamino, A. Dutartre, C. Flouhr, M. Juncker, N. Leleiva, N. Mary, P. Sasal and Soseto.

Samoa: We acknowledge the Samoan Ministry of Natural Resources Environment and Meteorology (MNRE), Conservation International (CI), The Japan International Cooperation Agency (JICA), the University of The South Pacific (USP) and the International Union for Conservation of Nature (IUCN). J. Atherton (CI) and N. Doherty (MNRE) played a major role in the mapping, coordination and logistic arrangements. With his presence in the field we are very happy to thank P. Gerbeaux.

We thank the Service de Systématique Moléculaire of the MNHN and its staff for allowing us to perform the molecular work.

\section{References}

Adamson, AM. 1935. Non-marine Invertebrate Fauna of the Marquesas (Exclusive of 

insects). Occas. Pap. B. P. Bish. Mus. 11(10): 1-39.

902

903

904

905

906

907

908

909

910

911

912

913

914

915

916

917

918

919

920

921

922

923

924

925

Adamson AM. 1939. Review of the fauna of the Marquesas islands and discussion of its origin. Occas. Pap. B. P. Bish. Mus. 159: 93p.

Atkinson JM. 1977. Larval development of a freshwater prawn, Macrobrachium lar (Decapoda, Palaemonidae), reared in the laboratory. Crustaceana 33(2): 119-132.

Bouvier EL. 1925. Recherches sur la morphologie, les variations, la distribution géographique des crevettes de la famille des Atyidés. (Encyclopédie Entomologique de Roret, Paris, France.)

Cai Y, Anker A. 2004. On a collection of freshwater shrimps (Crustacea; Decapoda; Caridea) from the Philippines, with descriptions of five new species. Trop. Zool. 17: 233-266

Cai Y, Ng PKL. 1999. A revision of the Caridina serrata species group, with descriptions of five new species (Crustacea: Decapoda: Caridea: Atyidae). J. Nat. Hist. 33: 16031638.

Cai Y, Ng PKL. 2001. The freshwater Decapod Crustaceans of Halmahera. Indonesia. J.

Crust. Biol. 21(3): 665-695.

Cai Y, Ng PKL. 2007. A revision of the Caridina gracilirostris De Man, 1892, species group, with descriptions of two new taxa (Decapoda; Caridea; Atyidae). J. Nat. Hist. 41(2528): 1585-1602.

Cai Y, Choy S, Ng PKL. 2009. Epigean and hypogean freshwater shrimps of Bohol Island, central Philippines (Crustacea: Decapoda: Caridea). Raffles B. Zool. 57(1): 65-89.

Cai Y, Shokita S. 2006. Atyid shrimps (Crustacea: Decapoda: Caridea) of the Ryukyu Islands, southern Japan, with descriptions of two new species. J. Nat. Hist. 40(38-40): 21232172.

Chinnaya B. 1974. The embryonic and larval development of Caridina weberi De Man in the laboratory (Decapoda, Atydae). Broteria. 43:119-134. 
926 Coleman CO. 2003. 'Digital inking': How to make perfect line drawings on computers. Org.

927 Divers. Evol. 3(Electronic Supplement 4): 1-14.

928 Coleman CO. 2006. Substituting time-consuming pencil drawings in arthropod taxonomy

929 using stacks of digital photographs. Zootaxa. 1360: 61-68.

930 Covich AP, Palmer MA, Crowl TA. 1999. The role of benthic invertebrate species in 931 freshwater ecosystems. BioScience. 49: 119-128

932 Craig DA., Currie DC., Joy DA. 2001. Geographical history of the central-western Pacific black fly subgenus Inseliellum (Diptera: Simuliidae: Simulium) based on a reconstructed phylogeny of the species, hot-spot archipelagoes and hydrological considerations. J. Biogeogr. 28: 1101-1127

Darriba D, Taboada GL, Doallo R, Posada D. 2012. jModelTest 2: more models, new heuristics and parallel computing. Nat. Methods. 9(8): 772-772.

De Grave S, Smith KG, Adeler NA, Allen DJ, Alvarez F, Anker A, Cai Y, Carrizo SF, Klotz W, Mantelatto FL, et al. 2015. Dead Shrimp Blues: A Global Assessment of Extinction Risk in Freshwater Shrimps (Crustacea: Decapoda: Caridea). PLoS ONE 10: e0120198.

De Man JG. 1892. Decapoden des Indischen Archipels. In: Weber, M, editor. Zoologische Ergebnisse einer Reise in Niederländisch Ost-Indien. Leiden (NL): Brill; p. 265-527.

Devick WS. 1991. Disturbances and fluctuations in the Wahiawa Reservoir Ecosystem. Hawaii Division of Aquatic Resource. F-14R-15.

946 Drummond AJ, Rambaut A. 2007. BEAST: Bayesian evolutionary analysis by sampling trees. BMC Evol. Biol. 7(1): 214.

948 Edgar RC. 2004. MUSCLE: multiple sequence alignment with high accuracy and high throughput. Nucleic Acids Res. 32(5): 1792. 
950 Edmondson CH. 1935. Atyidae of Southern Polynesia. Occas. Pap. B. P. Bish. Mus. 10(24): $951 \quad 3-40$.

952 Englund RA, Cai Y. 1999. The occurence and description of Neocaridina denticulata sinensis (Kemp, 1918) (Crustacea: Decapoda: Atyidae), a new introduction to the Hawaiian Islands. Bish. Mus. Occas. Pap. 58: 58-65.

Esselstyn JA, Evans BJ, Sedlock JL, Anwarali Khan FA, Heaney LR. 2012. Single-locus species delimitation: a test of the mixed Yule-coalescent model, with an empirical application to Philippine round-leaf bats. Proc. R. Soc. B 279 (1743): 3678-3686.

Ito A, Fujita Y, Shokita S. 2002. Larval stages of Macrobrachium australe (Guerin Meneville, 1838) (Decapoda: Palaemonidae), described from laboratory-reared material Crus. Res. 31: 47-72.

961

962

Falvo CA. 2013. Overcoming barriers: the climbing ability and distribution of three species of diadromous shrimp (A. pilipes, C. weberi, and Macrobrachium spp.) on Moorea, French Polynesia. UC Press, Biology and Geomorphology of Tropical islands.

Feldman C. 1996. Distribution and ecology of freshwater shrimp (Decapoda) in the Opunohu River, Moorea, French Polynesia. Biol. Geomor. Trop. Is. 5:151-162.

Felsenstein J. 1985. Confidence limits on phylogenies: an approach using the bootstrap. Evolution, 39(4), 783-791.

Fossati O, Marquet G. 1998. Faune des eaux douces des îles Marquises: clé des macroinvertébrés et des poissons. Paris: MNHN.

Fossati O, Mosseron M, Keith P. 2002. Distribution and habitat utilization in two atyid shrimps (Crustaceae: Decapoda) in rivers of Nuka-Hiva Island (French Polynesia). Hydrobiologia. 472:197-206

Guindon S, Gascuel O. 2003. A simple, fast, and accurate algorithm to estimate large phylogenies by maximum likelihood. Syst. Biol. 52(5): 696-704. 
Hayashi KI, Hamano T. 1984. The complete larval developpent of Caridina japonica De Man (Decapoda, Caridea, Atyidae) reared in the laboratory. Zool. Sci. 1: 571-589.

Heerbrandt TC, Lin J. 2006. Larviculture of red front shrimp, Caridina gracilirostris (Atyidae, Decapoda). J. World Aquacult. Soc. 37(2): 186-190.

Karge A, Klotz W. 2007. Süßwassergarnelen aus aller Welt. Etllingen (DE): Dähne Verlag.

Kearse M, Moir R, Wilson A, Stones-Havas S, Cheung M, Sturrock S, Buxton S, Cooper A, Markowitz S, Duran C, et al. 2012. Geneious Basic: an integrated and extendable desktop software platform for the organization and analysis of sequence data. Bioinformatics, 28(12): 1647-1649.

Keith P, Vigneux E. 2002. Revue des crustacés Atyidae et Palaemonidae d'eau douce de Polynésie française avec description d'une nouvelle espèce de Macrobrachium. B. Fr. Pêche Piscic. 364: 121-145.

Keith P, Vigneux E, Marquet, G. 2002. Atlas des poissons et des crustacés d'eau douce de Polynésie française. Paris (FR): MNHN.

Keith P, Marquet G. 2011. Poissons et crustacés d'eau douce de Wallis et de Futuna. Paris (FR): Société Française d'Ichtyologie.

Keith P, Marquet G, Gerbeaux P, Vigneux E, Lord C. 2013. Poissons et crustacés d'eau douce de Polynésie. Taxonomie, écologie, biologie et gestion. Paris (FR): Société Française d'Ichtyologie.

Keith P, Lord C, Maeda K. 2015. Indo-Pacific Sicydiine Gobies. Biodiversity, life traits and conservation. Paris (FR): Société Française d'Ichtyologie.

Kumar S, Stecher G, Tamura K. 2016. MEGA7: Molecular Evolutionary Genetics Analysis Version 7.0 for Bigger Datasets. Mol. Biol. Evol. 33(7): 1870-1874. 
Lessios HA, Kessing BD, Robertson DR, Paulay G. 1999. Phylogeography of the pantropical sea urchin Eucidaris in relation to land barriers and ocean currents. Evolution 53(3): 806-817.

Marquet G. 1988. Les eaux intérieures de la Polynésie française. Principales caractéristiques physiques, chimiques et biologiques [dissertation]. Paris (FR): Paris VI University.

Marquet G. 1991. Freshwater crustaceans of French Polynesia: Taxonomy, distribution and biomass (Decapoda). Crustaceana. 61(2): 126-140.

Martinez E, Ganachaud A, Lefevre J, Maamaatuaiahutapu K. 2009. Central South Pacific thermocline water circulation from a high-resolution ocean model validated against satellite data: Seasonal variability and El Nino 1997-1998 influence. J. Geophys. Res. 114: C05012.

Mary N, Dutartre A, Keith P, Marquet G, Sasal P. 2006. Biodiversité des eaux douces de Wallis et Futuna, Mission d'octobre 2004. Paris (FR): Ministère de l'Outre-Mer.

Mazancourt V de, Marquet G, Keith P. 2017. The 'Pinocchio-shrimp effect': First evidence of rostrum length variation with the Environment in Caridina H. Milne Edwards, 1837 (Crustacea: Decapoda: Atyidae). J. Crus. Biol. 37(3): 249-257.

Mazancourt V de, Klotz W, Marquet G, Mos B, Rogers DC, Keith P. 2019. The complex study of complexes: The first well-supported phylogeny of two species complexes within genus Caridina (Decapoda: Caridea: Atyidae) sheds light on evolution, biogeography, and habitat. Mol. Phylogenet. Evol. 131: 164-180

Mennesson M. 2016. Taxonomie, Phylogénie et Dispersion du genre Eleotris (Teleostei : Gobioidei : Eleotridae) dans l'Indo-Pacifique [dissertation]. Paris (FR): Muséum national d'Histoire naturelle. 
Miller MA, Pfeiffer W, Schwartz T. 2010. Creating the CIPRES Science Gateway for inference of large phylogenetic trees. In: Proceedings of the Gateway Computing Environments Workshop (GCE), New Orleans. p. 1-8.

Monaghan MT, Wild R, Elliot M, Fujisawa T, Balke M, Inward DJG, Lees DC, Ranaivosolo R, Eggleton P, Barraclough TG, Vogler AP. 2009. Accelerated species inventory on Madagascar using coalescent-based models of species delineation. Syst. Biol. 58: 298-311.

Nakahara Y, Hagiwara A, Miya Y, Hirayama K. 2005. Larval rearing of three amphidromous shrimps species (Atyidae) under different feeding and salinity conditions. Aquacult. Sci. 53(3): 305-310.

Page TJ, Choy S, Hughes JM. 2005. The taxonomic feedback loop: symbiosis of morphology and molecules. Biol. Letters. 1: 139-142.

Page TJ, Rintelen K von, Hughes JM. 2007a. Phylogenetic and biogeographic relationships of subterranean and surface genera of Australian Atyidae (Crustacea: Decapoda: Caridea) inferred with mitochondrial DNA. Invertebr. Syst. 21(2): 137-145.

Page TJ, Rintelen K von, Hughes JM. 2007b. An island in the stream: Australia's place in the cosmopolitan world of Indo-West Pacific freshwater shrimp (Decapoda: Atyidae: Caridina). Mol. Phyl. Evol. 43(2): 645-659.

Page TJ, Hughes JM. 2011. Neither molecular nor morphological data have all the answers; with an example from Macrobrachium (Decapoda: Palaemonidae) from Australia. Zootaxa. 2874: 65-68.

Palumbi SR. 1996. Nucleic acids II: the polymerase chain reaction. In: Hillis DM, Mable BK, Moritz C, editors. Molecular systematics. Sunderland (MA): Sinauer Associates. p. 205-247. 
Pelletier B. 2003. Apport des travaux de géologie et de géophysique de l'équipe IRD (Ex. ORSTOM) du centre de Nouméa à la compréhension de l'origine et de l'évolution des archipels de Wallis et Futuna. Rev. Géol, 137: 81-88.

Pillai NN. 1975. Larval development of Caridina pseudogracilirostris reared in the laboratory. J. Mar. Biol. Assoc. India. 17: 1-17.

Planes S. 1993. Genetic differenciation in relation to restricted larval dispersal of the convict surgeon fish Acanthurus triostegus in French Polynesia. Mar. Ecol. Prog Ser. 98: 237246.

Pons J, Barraclough TG, Gomez-Zurita J, Cardoso A, Duran DP, Hazell S, Kamoun S, Sumlin WD, Vogler AP. 2006. Sequence-based species delimitation for the DNA taxonomy of undescribed insects. Syst. Biol. 55: 595-609.

Poupin J. 1998. Crustacea Decapoda and Stromatopoda of French Polynesia. Atoll Res. Bull. 451:1-62.

Pringle CM, Blake GA, Covich AP, Buzby KM, Finley A. 1993. Effects of an omnivorous shrimp in a montane tropical stream: sediment removal, disturbance of sessile invertebrates and enhancement of understory algal biomass. Oecologia. 93: 1-11.

Puillandre N, Lambert A, Brouillet S, Achaz G. 2012. ABGD, Automatic Barcode Gap Discovery for primary species delimitation. Mol. Ecol. 21, 1864-1877.

Rambaut A, Drummond AJ. 2016. TreeAnnotator v1. 8.3. URL: http://beast.bio.ed.ac.uk/treeannotator.

Rambaut A, Suchard MA, Xie D, Drummond AJ. 2014. Tracer v1. 6. URL: http://beast.bio.ed.ac.uk/Tracer.

Resh VH, Barnes JR, Craig DA. 1990. Distribution and ecology of benthic macroinvertebrates in the Opunohu river catchment, Moorea, French Polynesia. Ann. Limnol. 26(2-3): 195-214. 
1070 Richard J, Clark PF. 2009. African Caridina (Crustacea: Decapoda: Caridea: Atyidae):

1071

1072

1073

1074

1075

1076

1077

1078

1079

1080

1081

1082

1083

1084

1085

1086

1087

1088

1089

1090

1091

1092

1093

1094

redescriptions of C. africana Kingsley, 1882, C. togoensis Hilgendorf, 1893, C. natalensis Bouvier, 1925 and C. roubaudi Bouvier, 1925 with descriptions of 14 new species. Zootaxa. 1995: 1-75.

Rintelen K von, Cai Y. 2009. Radiation of endemic species flocks in ancient lakes: systematic revision of the freshwater shrimp Caridina H. Milne Edwards, 1837 (Crustacea: Decapoda: Atyidae) from the ancient lakes of Sulawesi, Indonesia, with the description of eight new species. Raffles B. Zool. 57(2): 343-452.

Ronquist F, Huelsenbeck JP. 2003. MRBAYES 3: Bayesian phylogenetic inference under mixed models. Bioinformatics. 19(12): 1572-1574.

Rougerie F, Wauthy B. 1993. L'océanographie du Pacifique Central Sud. Encyclopédie de la Polynésie française. Paris (FR): Editions de l'ORSTOM.

Roux J, 1928. Notes carcinologiques de l'Archipel Indo-Australien. I. Décapodes macroures d'eau douce de l'Archipel Indo-Australien. Treubia 10: 197-216.

Stamatakis A. 2014. RAxML version 8: a tool for phylogenetic analysis and post-analysis of large phylogenies. Bioinformatics. 30(9): 1312-1313.

Shokita S. 2003. Atyidae, pp 249-254. In: Nishida M, Shikatani N, Shokita S, editors. The flora and fauna of inland waters in the Ryukyu Islands. Tokyo: Tokai University Press. 572 [in Japanese].

Teske PR, Papadopoulos I, Newman BK, Dworschak PC, McQuaid CD, Barker NP. 2008. Oceanic dispersal barriers, adaptation and larval retention: an interdisciplinary assessment of potential factors maintaining a phylogeographic break between sister lineages of an African prawn. BMC Evol. Biol. 8(341): 1-14.

Tiwari KK, Pillai RS. 1971. Atyid shrimps of the genus Caridina H. Milne Edwards, 1837, from the Andaman islands (Decapoda, Caridea). Crustaceana. 21(1): 79-91. 
Thomas MM, Pillai VK, Pillai NN. 1973. Caridina pseudogracilirostris sp. nov. (Atyidae: Caridina) from Cochin backwater. J. Mar. Biol. Assoc. India. 15: 871-873.

Vermeij GJ. 1987. The dispersal barrier in the tropical Pacific: Implications for molluscan speciation and extinction. Evolution. 41(5): 1046-1058.

Williams JL. 1999. The feeding ecology and effects of flooding on the tropical freshwater shrimp, Caridina weberi, (Atyidae). Biol. Geomor. Trop. Is. 8: 183-190.

WoRMS. 2018. Caridina H. Milne Edwards, 1837 [in H. Milne Edwards, 1834-1840]. Accessed at: http://www.marinespecies.org/aphia.php?p=taxdetails\&id=240672 on 2018-05-15

Zhang J, Sun X. 1979. Studies on the larval development of six freshwater prawn species in the middle and lower Chang Jiang (Yangtze) Valley. Acta Zool. Sinica. 25: 143-153.

Zhang J, Kapli P, Pavlidis P, Stamatakis A. 2013. A general species delimitation method with applications to phylogenetic placements. Bioinformatics, 29(22), 2869-2876.

Table 1. List of the specimens used in the $16 \mathrm{~S}$ phylogenetic study.

Figure 1. Map of the Polynesian triangle.

Figure 2. Bayesian Inference phylogenetic tree of the specimens studied. Numbers above branches indicate BI posterior probabilities, numbers under branches indicate ML bootstrap. Figure 3. Caridina futunensis n. sp. Holotype (MNHN-IU-2018-195; DNA: CA2118), a, b, c cephalothorax; d. first pereiopod; e. second pereiopod; f. third pereiopod; g. dactylus of third pereiopod; h. fifth pereiopod; i. dactylus of fifth pereiopod; j. preanal carina; k.first pleopod; 1. second pleopod.

Figure 4. Caridina marquesensis n. sp. Paratype (MNHN-IU-2017-71; DNA: CA2071), a. first pereiopod; b. first pereiopod detail of the fingertips; c. second pereiopod; d. third pereiopod; e. fifth pereiopod; f. dactylus of fifth pereiopod; g. dactylus of third pereiopod; h. 
1120 cephalothorax; i. preanal carina; k. uropodal diaeresis; 1. telson. Paratype (MNHN-IU-2017-

1121 69; DNA: CA2075), j. eggs. Holotype (MNHN-IU-2017-66), m. first pleopod; n. second

1122 pleopod.

1123 Figure 5. Caridina tupaia n. sp. Holotype (MNHN-IU-2018-260; DNA: CA2058), a. first

1124 pereiopod; b. second pereiopod; c. third pereiopod; d. fifth pereiopod; e. dactylus of fifth

1125 pereiopod; f. dactylus of third pereiopod; g. cephalothorax; h. preanal carina; j. uropodal

1126 diaeresis; k. telson. Paratype (MNHN-IU-2018-268), i. eggs. Paratype (MNHN-IU-2018-261;

1127 DNA: CA1048), 1. first pleopod; m. second pleopod.

1128 Figure 6. Caridina rapaensis. (MNHN-IU-2016-11771; DNA: CA2115), a. first pereiopod; b.

1129 first pereiopod, detail of the fingertips; c. second pereiopod; d. third pereiopod; e. fifth

1130 pereiopod; f. dactylus of fifth pereiopod; g. dactylus of third pereiopod; h. cephalothorax; i.

1131 preanal carina; $k$. uropodal diaeresis; 1. telson. (MNHN-IU-2015-1921: $\bigcirc$ ovig, $4.0 \mathrm{~mm}$ ), j.

1132 eggs. (MNHN-IU-2015-1921: đ̊, cl 2.9 mm), m. first pleopod; n. second pleopod.

1133 Figure 7. Live colouration of the species: A, B. C. tupaia n. sp.. C. C. marquesensis n. sp.. D,

1134 E. C. rapaensis. F. C. futunensis n. sp.. G. Habitat of C. futunensis n. sp. in Futuna. Credits:

1135 A, B, C: G. Marquet; D, E: E. Vigneux; F: V. de Mazancourt; G: A. Dutartre.

1136 Figure 8. Distribution map of the four species studied with oceanic currents of Southern

1137 Polynesia (from Martinez et al 2009) represented: SEC. South Equatorial Current. SECC.

1138 South Equatorial Countercurrent. MCC. Marquesas Countercurrent. STCC. South Tropical

1139 Countercurrent. GYRE. South Pacific Gyre.

1140 Figure 9. Map of the geology of the surroundings of Futuna Island (adapted from Pelletier $11412003)$. 